The Journal of SPORT, 2014, 3(1), 102-134

(C) Kent State University

\title{
Using a Sport Event within Coordinated Destination Marketing: A Case History of the New Mexico Bowl
}

\author{
John C. Barnes \\ University of New Mexico \\ Dan Ballou \\ Albuquerque Convention \& Visitors Bureau
}

\begin{abstract}
Sports events are important tools in the marketing of destinations. Events attract outsiders who provide economic impact. They also attract media attention that allows for a place to be seen in a favorable light as well as help position a city as a tourist destination for the event and in the succeeding years.

The purpose of this case study is to provide information and examples of cooperative marketing efforts by various destination marketing stakeholders within a community, based upon the development of an American college football bowl game. Included will be a brief discussion of the creation of the game as a place marketing tool, development of outside activities that are designed to add to the value perceived by visitors, and techniques used to encourage involvement by the various stakeholders in the local hospitality industry.
\end{abstract}




\section{Teaching Notes}

\section{Theoretical Areas and Applicable Courses}

The theoretical areas that coincide with this case study are related to place marketing. Place marketing, or place branding is ever-increasing in importance as competition between cities luring event producers has never been higher. With that, Destination Marketing Organizations are using sports events as a way to appeal and attract out-of-town travelers.

The term, 'place' may refer to a mechanism of distribution and also a physical location, such as a destination city or region (Schneider \& Bradish, 2006). As such, place marketing may be considered advertising and promotions that creates a positive place image, develops attractions for tourists, and improves infrastructure and quality of life within a community (Malecki, 2004). More specifically, if we are marketing a place as a tourist destination, place marketing and destination marketing are interchangeable terms and the strategies used to attract visitors are the same.

This case study is applicable to several departments on a campus. It would be beneficial to sports administration, hospitality management, and marketing programs campus-wide. Specific to sports administration, it would be part of curriculum in sports marketing courses, especially when dealing with destination marketing brand image, and how that image is used to attract visitors and worldwide media exposure through broadcast events. It would also fit well in a sports finance course and should be introduced in topical areas such as economic impact, public vs. private sector spending, using facilities to attract new customers, and the role a short-term event can play in increasing direct spending, and where those dollars are being spent.

The New Mexico Bowl case study could also be used in an event management class in facilitation discussions, and how representatives from several different local organizations came together to produce this game from the start. Dialogue pertaining to getting buy-in from the city, state, university, local media, local ticket-buying audience should be represented and role playing 
exercises could be done using this case study going back to when the game was just an idea and taking into account all the different attitudes that had to be brought together, discussed, and accepted before the decision was rendered on whether to move forward with the game.

\section{Discussion Questions}

1. Define all the appropriate stakeholders that would have an interest in the New Mexico Bowl, both from a local and nonlocal perspective.

a. The state of New Mexico - From the Governor's office when the announcement was made, to the Department of Tourism for implementation of the brand, how does the state benefit by sponsor involvement, and to what extent can it be insured the deliverables provide the benefits expected?

b. Department of Tourism - What is the best approach to market the state through the game and best mechanisms to reach the intended audience? Does the bowl game provide the necessary advertising inventory to appeal to the viewing audience in order to get them to consider coming to New Mexico at some point in the future? Is this measurable?

c. The Albuquerque Convention \& Visitors Bureau - As the flagship city in the state, what are the best and most effective ways to reach alumni groups and fans to not only get them to Albuquerque, but to also take advantage of the attractions the city has to offer once they are here? What strategies could DMO's in Albuquerque develop to increase the chances of attracting more of the targeted audience?

d. The University of New Mexico - The University of New Mexico plays a huge role in the bowl game. The university earns rent from the use of the stadium, and included in the rent is all the necessary staff required to host the game. From ticket sellers and takers, 
custodial, field maintenance, security, game management, sports information, athletic training, all the way to top-level administrators, the university has a heightened level of involvement in the game and must be involved in every aspect of its production.

e. Local Media - The local media play a very important role in spreading the word about the game in an effort to help promote ticket sales and attendance at ancillary events. The New Mexico Bowl must work on partnerships with the local media to effectively plan ticket buying campaigns and to help create a buzz about the game each year.

f. Corporate Sponsors - Sponsors play a large role in helping to insure that the game is successful from the local side of things. On the national level, the game's title sponsor (Gildan), helps provide the necessary financial footing required to keep the game in operation, and the local sponsorships, combined with local ticket sales, should be the most influential factors that keep the game profitable.

g. Ticket buying public - The local citizens, the ones who can make very quick decisions on whether or not to attend the game, are a key component to the bowl's success. These people should never be taken for granted.

2. With the very short time frame between the announcement of teams for the bowl game, and the game itself, there are advantages and disadvantages that were discussed. Name those advantages and disadvantages and which of the advantages offers the most benefit to the stakeholders in the bowl game?

a. Advantages - First bowl game of the season, fans are watching because the game kicks off the bowl season. Ratings have been good with more than 2.5 million viewers for each year of the bowl game thus far. The time frame of the bowl game does not force fans of 
the teams to give up holiday time because of the game's early bowl-season placement.

b. Disadvantages - The quick turnaround time from the announcement to the game does not give Destination Marketing Organization's a sufficient amount of time to extend marketing efforts into the destination market, alumni groups, or general fan base of the teams attending the game. With that, the opportunity to present the cognitive and affective benefits of the destination can be lost. It is also difficult to measure whether the limited marketing that can be done is effectively reaching the desired population.

3. From a marketing perspective, how might DMO's do a better job capitalizing on the television air time allotted for promotion of the destination?

a. One opportunity would be to replace general advertisements used to market the city and state and replace them with advertisements specific to the bowl game with a defined targeted demographic. Since the game has a history, and since it is apparently healthy and will remain for years to come, advertisements specific to sport would be appropriate. Advertisements created that include the Albuquerque brand highlighted as a specific sports destination could replace existing ads and have a lifespan of $2-4$ years.

4. Based on the case study, how successful do you think bowl games are, or sporting events as a whole, are in aiding the place marketing efforts of a particular city?

a. Sporting events can do a good job of promoting a city as a desirable destination through heavy promotion of attractions, resources, and other activities to take advantage of while in a city (both from an affective and cognitive approach). For a new event like the New Mexico Bowl, carving out some kind of niche or difference allows the game to stand out from the 
many other options. Because of the early timeframe of the game, it enjoys the tag of "first" bowl game of the season. Even though there is some evidence of drawbacks associated with that, it is likely a far better scenario than being buried amidst days when there are multiple bowl games televised, and the holiday season is in full swing. Care should be undertaken that bowl games (or other sports events), partner with DMO's to highlight all the positive aspects a destination has to offer (again, be it affective or cognitive), and the event should be used as a bridge to connect the traveler with the destination.

Information on how the challenge was addressed

The biggest issues associated with the New Mexico Bowl are the timing of the game itself in relation to the time of the bowl team announcements. This issue was discussed in the list of discussion questions.

\section{Coordinating in-class discussion}

In-class discussion could be done through an introduction of the New Mexico Bowl, and this case study to the students. Facilitation efforts could be done with role playing where selected students act the role of a representative from the list of stakeholders in question 1 in the Discussion Questions section. Through role playing, students could brainstorm potential ideas and marketing strategies that could prove beneficial to a destination's overall place marketing strategy while bringing to the forefront the concerns of the group they are representing.

Also, students could be split into groups and each group could develop additional strategies not included in the article. Ideas on how to more effectively gain market penetration in cities where potential New Mexico Bowl teams may come from could be developed from this strategy. Students should not be restricted to budgetary issues, or other logistical considerations, but rather they should be instructed to think outside the box. This would allow them 
to generate ideas, and once the ideas are generated, could be used as in-class discussion at which time the feasibility and reality of the ideas could be debated.

\section{Additional readings}

While all the references listed on the case study are related and provide solid information regarding the use of sports events to aid in destination marketing, industry journals specific to bowl games would be recommended. In particular, students truly interested in the bowl selection process could start by reading the Dan Wetzel's book, Death to the BCS. Another potential resource is Street \& Smith's Sports Business Journal which regularly runs information regarding bowl game payouts. Students would be well advised to monitor this publication on a regular basis.

SportsTravel Magazine is an option that regularly features destinations and what sporting events those destinations use to draw media attention and visitors to those cities. Shank's Sports Marketing: A Strategic Perspective is a great source for information specific to marketing. Journal of Vacation Marketing, International Journal of Event Management Research, Tourism Management, Journal of Sport Tourism, International Journal of Tourism Research, Tourism and Hospitality Research, Journal of Sport \& Tourism, are all research journals that pertain to this destination marketing and sport event tourism.

\section{Introduction}

Unlike nations, regions and cities can, to a certain extent, go out of business due to out-migration of people and businesses. This can leave a community at a competitive disadvantage within the tourism and economic market of communities. Thus, cities and regions must compete for outside investment, tourists, and work force. The upshot of competition between cities and regions is that it produces effects greater than just infrastructure improvement and media attention. It is a means of "compilation and distribution of information and data about a place" (Malecki, 2004, p. 1113). 
Within marketing theory, 'place' may refer to a mechanism of distribution and also a physical location, such as a destination city or region (Schneider \& Bradish, 2006). As such, place marketing may be considered advertising and promotions that creates a positive place image, develops attractions for tourists, and improves infrastructure and quality of life within a community (Malecki, 2004). More specifically, if we are marketing a place as a tourist destination we may look at place marketing as destination marketing. According to Elbe, Hallén, and Axelsson (2009), destination marketing is a culmination of three factors: 1) Activities performed by the Destination Marketing Organization (DMO) in order to build up legitimacy and foster cooperation, 2) Allocation and development of resources related to tourism, and 3) Destination integration in terms of relevant actors forming alliances. All of these components are interrelated in their roles in place marketing. Marketing of a place is related to economic development of the city or region by creating demand for a destination community. Marketing activities foster consumption (tourism) and that creates production, both factors of economic development (Oudan \& Luparelli, 2011).

Sports events are an important tool in the marketing of destinations. Events attract outsiders who provide economic impact. They also attract media attention that allows for a place to be seen in a favorable light (Chalip, Green, \& Hill, 2003). According to Hede (2005):

Special events, including sports events, are now playing an integral role in many destination marketing strategies. Some destinations are using sports events as a constant, and core component of their destination marketing strategies...Short-term sporting events of fixed duration...provide opportunities for host destinations to showcase their attributes to their visitors...(and) can change how host destinations are perceived and that they provide the new 'middle class tourist' with the impetus to visit host destinations in the future (p. 187-188). 
But those events are most effective when they can add to the 'saliency' of the overall place brand. This allows for generation of attitudes held by targets before, during, and after the event. The destination brand is beyond a logo or slogan, it is a reference to overall impression of the place that may be held in the minds of the consumer. It includes physical attributes, services, attractions, reputation, and benefits to the consumer (Chalip \& Costa, 2005). Although media attention to a sport event may not specifically affect potential tourists' intentions to visit a host community, television coverage may be used to help create a more positive way the community is perceived, in general (Brown, 2007).

The purpose of this paper is to use a case study technique to examine the development of a sport event that was created to provide a specific tourism attraction as well as how it is used in the overall marketing efforts of one destination region: The New Mexico Bowl college football game as a part of the destination marketing of the City of Albuquerque and the State of New Mexico. In a case study of the Athens 2004 Olympic Games and its media telecast, Hede (2005) noted that a case study approach is suitable when the subject matter focuses on current circumstances and does not require control over behavioral events.

Included in this case study will be a brief review of literature related to place/destination marketing and brand image, the use of specific events to enhance an overall destination marketing campaign, the integration of an event into the branding of the destination, a brief description of the New Mexico Bowl game, and how the game has been supported and exploited by the local tourism industry to enhance the destination marketing and branding of the State of New Mexico and the City of Albuquerque.

\section{Place/Destination Marketing and Brand Image}

According to Elbe, Hallén, and Axelsson (2009, p. 283), "Destination marketing is a concept used to denote deliberate, often strategically developed activities performed in order to attract visitors, i.e. tourists, to a specific location...Destination-management organizations (DMOs) are often given a central role in the marketing 
of a destination because they are created to take the overall responsibility for promoting tourism and for attracting visitors to the place or region defined as their domain". This also includes creating business tourism which lures conferences and conventions to a city. In addition, it includes the creation or attraction of hallmark events such as high profile sports and since these events are a scarce resource, competition among cities for them emerges, with the hopes of capturing 'mobile capital' (Malecki, 2004, p. 1108). Thus, a city can be treated as a 'product' that has utility/benefit for the tourist.

A place's image may be defined as "The sum of beliefs, ideas and impressions that people have of that place" (Gertner \& Kotler, 2004, p. 50). Destination marketers try to promote a favorable image of a community by developing a brand that contains all of the positive elements of that community's image. Branding allows a destination community to transmit messages regarding the qualities and benefits of the place to consumers (Chadwick \& Holt, 2008). There is an increase in the use of branding of tourist destinations in order to create positioning that creates an advantage in the destination marketplace. Destination brands are a "...strategic combination of 'a consistent mix of brand elements to identify and distinguish a destination through positive image building'... These elements, similar to the consumer products, are proposed to include terms, names, signs, logos, designs, symbols, slogans, color, packages, architecture, typography, photographic styles, as well as heritage, language, myths and legends" (Tasci \& Kozak, 2006, p. 301). As such, it makes sense to market a place as a brand, as the brand is essentially the culmination of the consumers' images of the components of the place (Elbe, Hallén, \& Axelsson, 2009).

Branding in destination marketing has unique characteristics and challenges. This is due in part to the fact that the destination 'product' is usually unchangeable and that tourism is heavily grounded in service, meaning it has the characteristics of a service: Perishability, inseparability, intangibility, heterogeneity " (Tasci \& Kozak, 2006).

Branding of cities is essentially the adoption of marketing strategies to create a brand image for the city or region. The basis of 
this is that a city can be seen as an object that can have a distinct identity that represents the characteristics of that city. In this sense, a city can be treated as a 'product' that has utility/benefit for the tourist. The city's brand image may be developed using community factors such as "...history, demography, economy, politics and policies. A city usually has certain identifiable images or core values perceived by its people" (Zhang \& Zhao, 2009, p. 245). And while there is consistency in a product that is, as mentioned above, unchangeable, there is a challenge in providing a consistent brand message that is the existence of diverse values and opinions held by the various stakeholders within the community itself. This challenge must be overcome in order to allow the brand to deliver images that are not in conflict with one another (Zhang \& Zhao, 2009). According to Fyall and Leask (2007), the destination is one of the most difficult products to market: Numerous products; Numerous stakeholders and organizational bodies; Numerous commercial entities. Therefore, because of the heterogeneity of a place stakeholders, attractions, etc., resources must be pooled and marketing must be done in a coordinated manner in order to keep branding and marketing messages consistent, as well as to get the most effect from marketing investment.

As brand image is the culmination of the relevant associations as linked to the destination brand, the destination brand image is based within a schema that holds nodes of info connected by associations. According to Chalip and Costa (2005):

Destination branding consists of fostering spreading activation to nodes that the marketer most wants associated with the destination brand. To do so, the marketer first identifies the most desirable and relevant nodes, and then works to create and strengthen the associations among them. (p. 222)

So, as Chadwick and Holt (2008) noted, understanding the array of associations, attachments, tourist self-identification and affiliation influences is of utmost importance in destination marketing. This also means that careful selection of significant marketing partners is critical. Developing destination brand equity 
therefore involves creating strategies that capitalize upon the understanding of sport tourist market segmentation rather than specifically branding for a perceived or desired market position.

As Zhang and Zhao (2009) wrote, the marketable properties and central beliefs of a city are largely determined by how the city is perceived by the target tourist market. Therefore, destination branding should be understood as being based on that market segment's interpretations of the city or region. Tourists tend to assess a destination community in concrete terms, focusing on issues such as culture, intra-city travel, climate, cost of living, recreation and sport facilities, and social make-up of the city. Zhang and Zhao (2009) use Anholt's (2007) aspects by which a community is understood and how a city's branding can be assessed. These can be categorized as:

\section{Aspect Meaning}

$\begin{array}{ll}\text { Presence } & \begin{array}{l}\text { The city's international status } \\ \text { and standing; the city's global } \\ \text { contribution. } \\ \text { The city's appearance and } \\ \text { physical attributes, such as } \\ \text { cleanliness of environment. } \\ \text { Place }\end{array} \\ \begin{array}{ll}\text { The city's opportunities for } \\ \text { future development. }\end{array} \\ \text { Pulse } & \begin{array}{l}\text { The city's vibrant and exciting } \\ \text { ways of life, with lots of } \\ \text { interesting activities for } \\ \text { residents and visitors. }\end{array} \\ & \begin{array}{l}\text { The city's friendliness, } \\ \text { openness, cultural } \\ \text { diversification and safety. } \\ \text { The city's basic infrastructure }\end{array}\end{array}$

and public amenities.

(Zhang and Zhao, 2009, p. 247) 
Gnoth, as written in Tasci and Kozak (2006) developed a model of tourism branding that took into consideration the different elements of branding in travel destinations:

1) Functional elements: Those emphasizing the destination's problem solving capabilities such as accessibility and reliability;

2) Symbolic elements: Those emphasizing the destination's ego enhancing attributes such as family, and affiliations with celebrities;

3) Experiential elements: Those emphasizing the destination's cognitive or affective attributes such as relaxation and learning.

How the New Mexico Bowl football game works within these two destination branding models will be discussed later in this paper.

\section{Sport Events used within Destination Marketing}

In their discussion of sport tourism, Deery, Jago, and Fredline (2004) utilize Gibson's definition of sport tourism as "...leisure-based travel that takes individuals temporarily outside of their home communities to play, watch physical activities or venerate attractions associated with these activities"(p. 235). In the late 1990's, sport event tourism grew to be the fastest growing segment within leisure travel.

Sport events are important methods for the development of urban and regional communities around the world, including in the U.S. (Kellett, Hede \& Chalip, 2008). According to Malecki (2004, p. 1107), "Tourism is an ill-defined sector that has risen in importance as both business tourism and leisure tourism have expanded greatly, sparking policies and building 'urban entertainment amenities' explicitly to attract visitors". The rationale for the use of sport events as tools for development of a community include: Creating an increase in tourism; Diminishing fluctuations in tourism due to seasonality; and, Creating proximal and general development within the community which, in turn, creates jobs (Chalip \& McGuirty, 2004) (Kellett, Hede \& Chalip, 2008). 
Both place marketing strategies and events within those strategies have been recognized as important for a host community (Chalip, Green \& Hill, 2003) (Wood, 2005). One benefit to hosting events is the direct economic impact they may create. Sport event tourism generates around $\$ 27$ billion per year in tourist spending. 75 million people in the U.S. reported having taken a sport event trip in the previous five years (Gibson, Willming, \& Holdnak, 2003). Furthermore, the tourism travel industry has not been left unaffected by the downturn in the U.S. economy. According to the U.S. Department of Commerce: Bureau of Economic Analysis (2011), there were 543,000 full- or part-time jobs in performing arts, spectator sports, museums, and related activities in 2010, down from 558,000 in 2008 , a decrease of 15,000 jobs or $2.7 \%$. Thus, communities may see the creation of specific sport events as a way to overcome the effects of a recessionary economy.

Perhaps more important to a community hosting a sport event - beyond its direct economic impact - may be the impact a sport event, especially one that is televised, has on raising the public awareness and shaping brand image of the host city or region (Chalip \& Costa, 2005). According to Hede (2005),

One premise of event-related destination marketing strategies is that images and information communicated of, and about, host destinations through events, particularly mega-events, have the capacity to create positive perceptions [of a destination] which will likely be associated with positive behavioural intentions [to visit the destination] in the future...As the telecasts of mega-events are now being used to extend this 'showcase' effect to media audiences outside the host destination, mega-events can therefore play an effective role in destination marketing strategies aimed at creating positive perceptions towards host destinations. (p. 189)

More and more, communities are using events such as the Olympic Games as a mechanism to help raise the profile and image of their city or region. This is believed to help attract outside 
investment and tourist visitors to the area and create a positive economic impact. "Media exposure makes it possible to create 'interest in a destination in the marketplace' ..., and a distinctive characteristic of mega-events is their ability to pull increasingly fragmented audiences back onto the major television networks" (Brown, 2007, p. 316). But sport events do not need to be megaevents to be beneficial to a host community. Gibson, Willming, and Holdnak, (2003, p. 188) noted, “...college sports events attract a significant proportion of fans from outside of the local community and as such, support the growing focus within the tourism literature that small-scale-sport tourism events may hold more benefit for a community than hosting mega-events".

\section{Maximizing the Benefits and Impacts of a Destination Sport Event}

Exploiting a destination sport event, in part means enhancing the event's direct impacts. Direct impact is the generation of spending in the host community by non-residents. This means that the host community must attract non-resident consumers to the community and attend the event. The design of the experience and how it is displayed in advertising is an important factor in affecting sport tourists travel choice (Harrison-Hill \& Chalip, 2005). Perhaps more importantly, event managers and organizers must know which market segments are interested and attracted to which specific events. Marketing of destination events is driven by branding of the event and brand positioning statements that help with communicating the event to specific market segments (Getz \& McConnell, 2011). A consumer will choose a particular travel destination if it provides more benefits than any other alternative...including staying home. This guides the DMO to design experiences and promotions that are perceived by the target consumer to be most beneficial (Snelgrove, Taks, Chalip, \& Green, 2008).

There are three types of motives for travelling to sport events: 1) Being a fan of the sport; 2) Leisure opportunities; 3) Identification with the subculture of the sport event (Snelgrove, 
Taks, Chalip, \& Green, 2008). Sports can create subcultures by fostering socialization fans towards the adoption of the attitudes, beliefs, and values associated with the sport or team. This creates a self-identity with the subculture of the sport or team can drive consumption choices where the consumer makes purchasing decisions that will help them display or represent the values of the subculture...Including sport event travel decisions. Thus, the identification with a sport subculture has an effect on a consumer's decision to attend a sport event. As Snelgrove, Taks, Chalip, \& Green (2008, p. 167) noted, "...fan behaviors and attitudes are driven by fans' motives. In other words, the expectation is that the higher one's fan motivation, the more likely it is that one will care about and consume sport entertainments".

Getting sport event tourists to take advantage of other attractions and services within the host community is another way to maximize the direct effects of a destination sport event. This may be enhanced by the cooperation and collaboration of DMOs and the service providers in the community, who can develop strategies to make tourists more aware of other attractions and create special events to attract that particular group (Gibson, Willming, \& Holdnak, 2003) That being said, sport event tourists are more likely to be involved in regular tourist activities if they stay in a host community for more than 24 hours. Therefore, it is incumbent upon DMOs to create a total package of interrelated activities designed to encourage sport tourists to stay for more than one day. In addition, DMOs who are attempting to build their brand through a single sport event must create an assortment of ancillary events. "A single event - even one with a high profile - has only a passing effect on the destination brand" (Chalip \& Costa, 2005, p. 231).

Sport tourists tend to be aggressive in their searches for details on events to attend. They are also particular about the associated attractions of a sport event. They seek 'bundles of benefits'. It will be important for the local DMO and associated businesses to strategically incorporate ancillary events into the mix of available events and attractions within the event community or region. Providing more attractions related to the event will create 
more perceived value for the potential tourist (Chalip \& McGuirty, 2004).

Enhancing the sport tourist's experience in a particular destination may be aided by providing multiple events and bases for affective involvement. This creates a deeper emotional involvement for the tourist by providing meaning to them through narratives, genres, and symbols (ie: flags, posters, murals, emblems that are displayed throughout the area during the time of the event). Harrison-Hill, and Chalip (2005). refer to this as "experience marketing" (p. 306). Experience marketing seeks to engage the sport tourist on many levels, including physical, emotional, intellectual, and even spiritual. This involvement can occur through two means participation in activities and immersion in the experience. This allows for the consumer to have a more 'authentic' experience within the host community. The authors provide four factors that will enhance repeat sport tourist visitation: 1) A distinct sport servicescape (p. 307); 2) Good infrastructure and service; 3) Socializing opportunities; 4) Effective narratives, symbols, and genres. The servicescape is the physical environment in which the service takes place. This presents a challenge to the marketer as the physical characteristics of the servicescape cannot be altered to meet the wants and needs of the sport consumer. However using relevant theming related to the sport event can be used to embellish the servicescape and make it more appealing to the consumer. Service providers are also a part of shaping the consumer experience. Since the servicescape is a fixed asset and cannot be altered, customer service is important in shaping tourist experiences. Finally, the presence of other customers who are travelling to a particular destination have a profound influence on the experience of the sport tourist. Socializing activities with others is a large influence on a sport tourist's decision to travel to a particular destination. Sport event visitors will sometimes stay in the city of the event beyond the time of the event, in order to spend more time with other likeminded tourists. This practice can be enhanced by local businesses that provide event-associated themes, signage, and promotions (Chalip \& McGuirty, 2004). 
It may be of use for DMOs to include activities and signage with themes that evoke memories related to the teams, personalities, and events of earlier times in order to attract sport tourists. As Gibson (2005, p. 136) noted, it may be important to showcase ...the nostalgia that is evoked by visiting tangible sites of former sporting glory such as sports stadia or museums, nostalgia can also be evoked by a group of sport tourists who have a history of participating together in a particular experience, such as an annual bus trip to watch their football team play.

\section{Integration of a Sport Event into Overall Destination Marketing}

While the integration of a sport event into the overall destination marketing and branding of a city or region is seen as an effective way to directly and indirectly increase tourism to the host community, it must be done with care and careful planning. This is due to factors related to the event as well as factors related to the host community brand.

First, successful community branding is enhanced by finding a way to portray the city's distinctive qualities in ways that are easily understood by the target audience, harmonious with established beliefs held by that audience, and consistent (Zhang \& Zhao, 2009). This means that the branding of the event should be related to the positive elements of the existing brand image of the community. It also means that the connection of the brand of the event should be recognizable to target consumers as being consistent with that of the community in general. Sport events are most effective when they can add to the 'saliency' of the overall place brand. This allows for generation of attitudes held by targets before, during, and after the event. As Chalip and Costa (2005, p. 219) wrote, "Branding a city or a region in order to promote tourism requires that available attractions and activities be identified and, if necessary, augmented or enhanced in a manner that is consistent with the brand image that the destination seeks to convey". In other words, the brands of the event and the destination are judged more favorably by the targets if they are congruent with one another...likely creating greater image 
associations. Images of each should be 'conceptually consistent' with each other (Chalip \& Costa, 2005). Harrison-Hill and Chalip (2005) echoed this contention and went even further by stating that not only should the event and the host community feature congruent brand image elements, they should also be marketed jointly. In this regard they wrote,

Bundling and co-branding share the requirement that destinations and the sport they host are marketed jointly. The sport is used to promote the destination, and the destination is leveraged to promote its sport. By capitalizing on the two simultaneously, each adds value to the other. This, in turn, requires that destination marketers and sport marketers form alliances to plan and implement the necessary marketing strategies. (p. 313)

Thus, a destination's image is affected by the image of the events it hosts. How much affect will be determined by the congruence of the event and the place (Chalip, Green, \& Hill, 2003). This notion is similar to the branding of product extensions in that success in the co-branding of a product (in this case, the host community) and an extension of that product (in this case, the sport event) requires that the "event's inclusion in the destination's product and service mix should appear rational. In other words, it needs to be shown that the event fits with other attractions and activities offered at the destination" (Chalip \& Costa, 2005, p. 227).

Some destinations have a market position advantage in that they have historical relevance and/or they are in locals with favorable climates and geographic appeal. Events in these destinations have an advantage in attracting tourists. Events in destinations without an historical or geographic advantage may benefit from bundling or packaging their event with other elements of the place (Getz \& McConnell, 2011). At the very least, the branding for the destination should be valid, believable, simple, not confusing, appealing (to the target consumer), and distinctive (Gertner \& Kotler, 2004). 
Two major roadblocks to the creation and maintenance of a consistent and congruous brand image of a community and a sport event in that community are the multitude of stakeholders within the community and the heterogeneity of the community. First, there is a challenge in providing a consistent brand message due to the existence of diverse values and opinions held by the various stakeholders within the community itself. Creating associated events is hindered by the fact that Destination Marketing Organizations (DMOs) and hospitality businesses often do not work together to coordinate the events (Chalip \& McGuirty, 2004). This challenge must be overcome in order to allow the brand to deliver images that are not in conflict with one another (Zhang \& Zhao, 2009). Thus, in order to better leverage a sport event for economic and social benefit, coordination of involvement by public and private entities is necessary (Kellett, Hede, \& Chalip, 2008). This is especially true if the community wishes to realize tourist consumption of other various attractions within the community. It is important for DMOs to understand that just because sport event tourists will come to a community for an event, they will not automatically utilize the other attractions and services in the community.

Getting sport event tourists to take advantage of those other attractions and services may be enhanced by the cooperation and collaboration of DMOs and the service providers in the community, who can develop strategies to make tourists more aware of other attractions and create special events to attract that particular group (Gibson, Willming, \& Holdnak, 2003).

Place heterogeneity is an issue that may also hinder the development of a consistent brand image. Because of the heterogeneity of a place - stakeholders, attractions, etc., resources must be pooled and marketing must be done in a coordinated manner in order to keep branding and marketing messages consistent as well as to get the most effect from marketing investment. As Fyall and Leask (2007) noted,

One of the primary frustrations for many destination marketers is their inability to control elements of the destination product...the difficulties of co-ordination 
and control have the potential to undermine a strategic approach to marketing based on destination branding because campaigns can be undertaken by a variety of tourist businesses with no consultation or coordination on the prevailing message or the destination values being promoted. (p. 55)

Again, creating and maintaining consistent brand image and brand messages is of major importance in overcoming these challenges. When a brand has a consistent message, consistent logo and colors, consistent images, etc., it is cohesive in the mind of the consumer. This means that the consumer has more detailed information about the brand and the product. It also means that the fit between each element within the brand schema fits well. When this occurs, the consumer sees and understands the connections between these elements. According to Gwinner and Bennett (2008),

Brand cohesiveness can be thought of as a measure of internal brand congruence. Keller (1993, p. 7) states that the "congruence among brand associations determines the 'cohesiveness' of the brand imagethat is, the extent to which the brand image is characterized by associations or subsets of associations that share meaning". Thus, brands that have developed non-ambiguous meanings are more cohesive than those brands whose meanings are more diffused. A brand's image will be more cohesive to the extent that it has maintained the same positioning over time, has used consistent images (e.g., logos, colors, endorsers, slogans, etc.) in its promotional efforts, and has cultivated associations with other entities (e.g., sponsorship activities) that share a similar theme. (p. 413)

DMOs and event organizers should utilize tactics related to media coverage of the event in order to help create brand cohesiveness and a consistent brand image of a sport event within a destination community. Although media attention to a sport event may not specifically affect potential tourists' intentions to visit a host 
community, television coverage may be used to help create a more positive way the community is perceived, in general (Brown, 2007). This may entail infusion of local place culture in the brand and the marketing messages as well as the event itself (Fyall \& Leask, 2007). For example, the New Mexico Bowl creates a new and unique trophy to be given to the winning team each year. This trophy is a ceramic bowl that is hand-maid and hand-painted by artists from one of the many Native American pueblos within the state.

The bottom line here is that the value of creating and hosting a sport event will be based, in part, on the ability of the sport event brand to, as Xing and Chalip (2006, p. 54) noted, "strengthen relevant aspects of the destination's brand".

\section{History of the New Mexico Bowl Game}

The first New Mexico Bowl game was played on December 23,2006 . That first game was the culmination of several months of accelerated negotiations and preparation to devise and define the game as well as to establish funding, create sponsorships, and generate all of the activities that surround a college football bowl game. The New Mexico Bowl was a creation of the New Mexico Sports Authority. The Authority proposed the idea to ESPN Regional Television (ERT) midyear in 2005, with the idea of matching up two leagues with prominent history in collegiate athletics in the state - the Mountain West Conference and the Western Athletic Conference (WAC). The automatic tie-in with the WAC ended prior to the 2011 bowl game and the current matchup features a member of the PAC-12 Conference. Although these conferences have automatic entries into the game, a member conference must have the required number of wins to be bowl eligible. This was not the case in the 2010 and 2011 games, as two non-affiliated conference schools were extended invitations to the game - University of Texas, El Paso in 2010, and Temple University in 2011.

The New Mexico Bowl was proposed to the NCAA Bowl Certification Committee in April of 2006 and awarded the same day. Two other bowl games were also awarded at the time: The 
International Bowl in Toronto (no longer in existence) and the BBVA Compass Bowl in Birmingham, Alabama.

In its first five years, the game lacked a true title sponsor and was simply known as the New Mexico Bowl. In 2011, ERT and Gildan, a Canada-based apparel manufacturer agreed to a five-year title sponsorship of the game. The current official title is the Gildan New Mexico Bowl. As part of the original arrangement when the bowl game was being created, the local organizing committee (LOC) insisted that "New Mexico" always would be part of the title and could never be removed as the LOC felt the identification of the bowl game as a geographical indicator would help aid in the marketing of the destination (J. Siembieda, personal communication, August 2, 2012). This was a logical decision as prior to the Gildan sponsorship that started in 2011, the Albuquerque Convention and Visitors Bureau and the New Mexico Department of Tourism were the two major sponsors of the event. And even with the new title sponsorship, both organizations continue their relationship with the game today.

The New Mexico Bowl became the sixth bowl game of seven owned and operated by ESPN, the others being the Pioneer Las Vegas Bowl, Sheraton Hawai i Bowl, Bell Helicopters Armed Forces Bowl, PapaJohns.com Bowl, the St. Petersburg Bowl, and the Texas Bowl. The Las Vegas bowl was the first bowl game acquired by ERT, and the Hawai'i Bowl was the first game the network started from inception.

ESPN ventured into the world of bowl game ownership and operation as a means of extending the ESPN brand into host communities, and the brand is strengthened by the programming platform they provide. Regardless of the size of a bowl game, or the perception a game might have on national ranking implications, they tend to rate well (Overby, 2012). This is an important factor for the marketing of New Mexico as the reach of images and messages related to the community is extensive. According to ESPN's 2010 New Mexico Bowl Partnership Review (ESPN, 2011), that reach was substantial. Based upon media equivalency figures, Albuquerque Convention and Visitors Bureau in-game signage and 
mention exposure time value was estimated to be $\$ 1,245,270$, City of Albuquerque signage and mention value was $\$ 732,330$ and, signage and mention value for the ACVB web site address, itsatrip.org was $\$ 661,260$. Furthermore, taking into account media equivalency values for exposure beyond the live broadcast (mentions and signage on ESPN programming and in national press coverage of the game), the total value of the game as a promotional tool for the City Albuquerque and State of New Mexico was \$6,752,060.

\section{The New Mexico Bowl and Destination Marketing}

Successful use of a sport event in order to enhance a destination image may be dependent upon how well the important attributes of the brand of the host community and the brand of the event match up. This contention is grounded in schema theory and the basic types of association factors might include attributes of the product, personality of the brand, user imagery, and experiential and symbolic benefits to the consumer (Xing \& Chalip, 2006). Understanding this, it is beneficial to examine how well these factors match between the brands of the New Mexico Bowl and of the host communities. Destination marketers in the city and state were assigned the task of matching the bowl game events with the attractions, cultures, cuisines, affordability, and other areas used in a typical destination marketing campaign or convention selling process in the Albuquerque metro region. Understanding that, the brand imagery the Albuquerque Convention and Visitors Bureau, as well as the State of New Mexico Department of Tourism, has been related to educating meeting planners, sports event organizers, tourists, and leisure travelers about the city and state and what they have to offer visitors.

Chalip and Costa (2005) asserted that tourists, leisure travelers, or fans of sports teams will use both cognitive and affective descriptions of a destination. Albuquerque and the state of New Mexico promote the cognitive images of its southwestern landscape, numerous outdoor activities, and how those natural resources have been combined with manmade structures in an effort to allow humans the opportunities to access these resources. The 
Sandia Peak Aerial Tramway, National Park Service trail systems, Rio Grande Valley Nature Centers, et al, are activities highlighted in bowl week, and marketed by the ACVB to the New Mexico Bowl staff as opportunities for which the teams may take advantage. The ACVB also puts these features into promotional materials for use with both teams' fans. As a membership driven organization, the Albuquerque CVB goes to great lengths in associating its member businesses with convention delegates, leisure travelers, and those fans coming in to the New Mexico Bowl, or any other sporting event the city hosts.

In its March 2006 Albuquerque's Destination Master Plan (Harvey, et al, 2006, p. 3), organizations and leaders promoting Albuquerque as a destination led off the document with the following mission statement: "We will make Albuquerque a world class destination by preserving and promoting our authentic Southwest heritage, rich culture, dramatic landscape, and spectacular climate." This has been evident in many aspects of the marketing and game-week activities of the New Mexico Bowl. A key component of the marketing campaign to incoming fans is to immediately immerse them into the culture of the area right away. One of the easiest ways to introduce the Southwest heritage is through the cuisine that is specific to Albuquerque and in New Mexico. Through the use of advertising collateral that shows photos of the food, the goal is to promote ACVB member dining options as early in the overall marketing process as possible.

Other cultural aspects are featured in the initial marketing stages for visiting fans. Some of these relate to topics of interest that again are unique to the area. Albuquerque bills itself as the hot air ballooning capital of the world as evidenced by the long-running success of the Albuquerque International Balloon Fiesta. Another highlighted area is historic Old Town, where Albuquerque was originally settled more than 300 years ago, and now is the site of the aforementioned New Mexico Bowl pep rally. The Old Town Merchants Association benefits from the pep rally though exposure to out of town visitors numbering in the low thousands who, without the New Mexico Bowl, would likely never have been in 
Albuquerque on a Friday evening in December, exploring the area and experiencing the modern day delicacies and shopping opportunities in original adobe structures, some of which are nearly 300 years old.

The dramatic landscape of the area is highlighted during bowl week by exposing visitors to Sandia Peak via the Sandia Peak Aerial Tramway. Fans can take flights to the top of the peak with 50 people in each "tram". Once at the top, more than 11,000 square miles of desert and mountain landscapes are available to the naked eye. These are all examples of the cognitive imagery Chalip and Costa (2005) asserted will help make a destination attractive to visitors.

The ACVB and State Tourism Department also use an affective approach in marketing Albuquerque as a destination through the New Mexico Bowl. This is done through the use of four affective descriptors targeted during the decision-making phase for visitors to the city, as well as for those contemplating traveling to Albuquerque for the bowl game. The four descriptors are: affordability; accessibility; attractions; activities. It is acknowledged that these are common terms that many cities would use to describe their destination marketing efforts, especially in the Midwest and Southwest Regions of the United States. It should also be noted that cities in these regions adjust their pricing depending on the time of the year. As an example, prices visitors would expect to pay in Phoenix in summer months are far less expensive than prices from October to May, and the same reasoning holds true with destinations that offer winter skiing, or some other element justifying an increase based on seasonality.

The affordability component refers to the cost of various travel methods to reach a destination, the cost of lodging, rental cars, or public transportation, as well as meals. With the limited time inherent to most bowl game travel, the ACVB and Department of Tourism promote the use of e-coupons and other options of saving money once fans get to Albuquerque. Realizing that short term flights are typically higher priced and out of the control of the destination marketing organizations, the destination marketers really 
amp up the efforts to promote the affordability of the destination once fans arrive. This element is something that is much more controllable. Albuquerque has long been marketed as an affordable destination overall, so it is crucial to provide information to incoming fans regarding the heightened levels of attractions and activities in relation to the attenuated levels of relative cost to enjoy them.

Accessibility is related to the different ways travelers can get to a destination. As mentioned, the expense related to getting to a city is out of the control of the local destination marketing organizations. With that, when introducing the destination to visitors who likely don't know much about the city, it is imperative that the ACVB provides all accessibility options to fans. This is related to a previous statement in this article and how important the education process is in the overall decision making process.

One other aspect that should be given careful consideration is the scenario that occurs for the New Mexico Bowl regarding team announcements. This component is critical as the destination marketing strategies are given very small windows to be put in place. The early date of the New Mexico Bowl provides a unique opportunity. Because the game has been the first bowl game of the bowl season for the last six years, TV ratings have been strong, with more than 2.5 million views each year regardless of the game's matchup (Overby, 2012). The ratings are crucial to the destination's exposure through the use of bumper shots coming in and out of commercial breaks. These bumper shots are extremely crucial to the destination because the ACVB has a lot of input on the content used in the buffer shots. Credit ERT for trusting that as the marketing arm for the destination, the ACVB is highly tuned to what the most effective visuals are when selling the destination. Often times, ACVB or Department of Tourism B-Roll footage is provided to supplement the live broadcast of the game. The sponsorships with the ACVB, and the Department of Tourism hinge on the level of image exposure the destination obtains during the broadcast. Since the game has proven to have a strong level of viewership as the first 
bowl game of the season, this is likely the most important component of the sponsorship fulfillment.

One crucial element that must be considered is the time available to put any type of marketing strategy in place. Consider that in 2011 the bowl announcements took place in early December, not quite two weeks prior to the game meaning that full-force marketing efforts started immediately to capitalize on the excitement of fans following the team announcements. The strategy applied by the ACVB is to immediately contact the alumni association of the schools selected to start the process of providing them lodging and attraction information.

Also the ACVB sends out ticket envelope stuffers with photos of the items mentioned previously in the cognitive selling process (cuisine, ballooning, mountains). These stuffers are the quickest way to direct fans to website information pertaining to the bowl game and the city itself. While the announcement of the teams coming to the game comes late, these are marketing items that can be prepared regardless of the teams selected. Once the teams were known, these deliverables are then put into place so that fans who are buying tickets to come, have access to attractions and activities as soon as the tickets are in their possession.

The New Mexico Bowl has benefitted on three different occasions with teams that were from markets relatively close to Albuquerque (Fort Collins, Colorado; Laramie, Wyoming; El Paso Texas) and ending bowl game droughts. This situation is a destination marketer's dream come true, in that the marketing effort does not need to be as dependent on time and penetration in to that market as would Fresno, California. However, what the quick turnaround time does not allow is for extensive media penetration in each school's home market. With Temple University in the 2011 game, the Philadelphia market would have been one that would have had large appeal as a targeted market to educate and create exposure for the city and state in a market not typically designated as a targeted area.

As one of the major sponsors of the Gildan New Mexico Bowl, the Albuquerque Convention \& Visitors Bureau receives a 
Total Exposure Valuation provided by ESPN soon after the broadcast. ESPN breaks down the various exposure areas and itemizes the value of each. The table below (Table 1) itemizes those varying exposure sources and assigns dollar values to them (ESPN, 2013).

\begin{tabular}{lllll}
\hline $\begin{array}{l}\text { Exposure } \\
\text { Source }\end{array}$ & $\begin{array}{l}\text { Exposure } \\
\text { Time }\end{array}$ & $\begin{array}{l}\text { \# of } \\
\text { Mentions } \\
\text { /Articles }\end{array}$ & Impressions & $\begin{array}{l}\text { Exposure } \\
\text { Value }\end{array}$ \\
\hline National Television & $0: 28: 27$ & 30 & $19,171,392$ & $\$ 1,760,480.00$ \\
Television News & N/A & 70 & $2,082,720$ & $\$ 36,260.16$ \\
On-site impact & N/A & N/A & 0 & $\$ 0.00$ \\
Advertising/Promotion & N/A & N/A & 0 & $\$ 0.00$ \\
s & N/A & 356 & $39,125,904$ & $\$ 685,003.40$ \\
Print Media & N/A & 1,063 & $43,296,589$ & $\$ 753,793.62$ \\
Internet News & $0: 28: 27$ & 1,519 & $103,676,605$ & $\$ 3,235,537.23$ \\
Total & & & & \\
\hline
\end{tabular}

Table 1

Chalip (2006) stated two elements vital for creating liminality at sports events: The sense of celebration and the sense of social camaraderie. The celebration occurs at the end of a long season, and fans and participants come together to rejoice in a successful season. This occurs during the New Mexico Bowl often at pre-game pep rallies or during tailgating opportunities, at bowlsponsored events, or at university or alumni-produced festivities. While these events are often attended en masse as part of a process of bringing strangers together due to a common bond (Chalip, 2006), the celebrations, and eventually the game itself, are normally attended and viewed by those who were previously acquainted.

Within college bowl games history, the Gildan New Mexico Bowl is in its infancy. Ironically though, Albuquerque is one of the oldest cities in the United States, having celebrated it's tricentennial in 2010. The similarities though that exist between the bowl game 
and the city, and the entire state for that matter, are that the game, the city, and the state are not necessarily top-of-mind in each of their respective categories. What makes the bowl game a potential boon is that it provides much-needed exposure for a city and state that struggles with unfamiliarity at the national level. Albuquerque and the state of New Mexico are areas that benefit from the experience visitors have when they visit the destination. The dilemma has not necessarily been during the visit itself, but the process of getting convention goers, leisure travelers, and now bowl fans to consider the destination at all. The hope that lies with the Gildan New Mexico Bowl is that it invigorates the education process of travelers so that the city and state move up the list of desirable southwestern locations. 


\section{References}

Brown, G., 2007. Sponsor hospitality at the Olympic Games: An analysis of the implications for tourism. International Journal of Tourism Research, 9, 315-327

Chadwick, S. \& Holt, M. (2008). Releasing latent brand equity: the case of UEFA's Champions League. The Marketing Review, 2008, 8(2), 147-162.

Chalip, L. \& Costa, C. 2005. Sport event tourism and the destination brand: Towards a general theory. Sport in Society, 8(2), 218237.

Chalip, L., Green, B., \& Hill, B. (2003). Effects of sport event media on destination image and intention to visit. Journal of Sport Management, 17, 214-234.

Chalip, L. \& McGuirty, J. (2004). Bundling sport events with the host destination. Journal of Sport Tourism, 9(3), 267-282.

Deery, M., Jago, L., \& Fredline, L. (2004). Sport tourism or event tourism: Are they one and the same? Journal of Sport Tourism, 9(3), 235-245.

Elbe, J., Hallén, L. \& Axelsson, B. (2009). The destinationmanagement organisation and the integrative destinationmarketing process. International Journal of Tourism Research, 11, 283-296.

ESPN Regional Television. (2013, February). 2012 New Mexico Bowl Total Exposure Valuation. Charlotte, NC: ESPN Regional Television.

ESPN Regional Television. (2011, June). 2010 New Mexico Bowl Partnership Review Report. Charlotte, NC: ESPN Regional Television.

Fyall, A. \& Leask, A. (2007). Destination marketing: Future issues - Strategic challenges. Tourism and Hospitality Research, $7(1), 50-63$.

Gertner, D. (2011). Unfolding and configuring two decades of 
research and publications on place marketing and place branding. Place Branding and Public Diplomacy, 7(2), 91106.

Gertner, D. \& Kotler, P. (2004). How can a place correct a negative image? Place Branding, 1(1), 50-57.

Getz, D. \& McConnell, A. (2011. Serious sport tourism and event travel centers. Journal of Sport Management, 25, 326-338.

Gibson, H. (2005). Sport tourism: Concepts and theories. An introduction. Sport in Society, 8(2), 133-141.

Gibson, H., Willming, C., \& Holdnak, A. (2003). Small-scale event sport tourism: Fans as tourists. Tourism Management, 24, 181-190.

Gwinner, K. \& Bennett, G., 2008. The impact of brand cohesiveness and sport identification on brand fit in a sponsorship context. Journal of Sport Management, 22, 410-426.

Harrison-Hill, T. \& Chalip, L. (2005). Marketing sport tourism: Creating synergy between sport and destination. Sport in Society, 8(2), 302-320.

Harvey, B., Kelsay, D. \& Russell, D. (2006). Albuquerque's Destination Master Plan (March 2006). Willard, Missouri: Egret Communications.

Hede, A. (2005). Sports-events, tourism and destination marketing strategies: an Australian case study of Athens 2004 and its media telecast. Journal of Sport Tourism 10(3), 2005, 187200.

Kellett, P., Hede, A., \& Chalip, L., (2008). Social policy for sport events: Leveraging (relationships with) teams from other nations for community benefit. European Sport Management Quarterly, 8(2), 101-121.

Kotler, P. \& Gertner, D. (2002). Country as brand, product, and beyond: A place marketing and brand management perspective. Brand Management, 9(4-5), 249-261.

Malecki, E. (2004). Jockeying for position: What it means and why it matters to regional development policy when places compete. Regional Studies, 38(9), 1101-1120. 
Oudan, R. \& Luparelli, A., 2011. Marketing and growth strategies for emerging economies: A case-study of Trinidad and Tobago. International Business \& Economics Research Journal, 10(10), 71-81.

Schneider, R. \& Bradish, C. (2006). Location, location, location: The marketing of place and Super Bowl XL. Sport Marketing Quarterly, 15(4), 206-213.

Shibli, S. \& Coleman, R. (2005). Economic impact and place marketing evaluation: A case study of the World Snooker Championship. International Journal of Event Management Research, 1(1), 13-29.

Snelgrove, R., Taks, M., Chalip, L., \& Green, C. (2008). How visitors and locals at a sport event differ in motives and identity. Journal of Sport \& Tourism, 13(3), 165-180.

Tasci, A. \& Kozak, M. (2006). Destination brands vs. destination images: Do we know what we mean? Journal of Vacation Marketing, 12(4), 299-317.

U.S. Department of Commerce: Bureau of Economic Analysis. (December 13, 2011).

Wood, E. (2005). Measuring the economic and social impacts of local authority events. International Journal of Public Sector Management, 18(1), 37-53.

Xing, X. \& Chalip, L. (2006). Effects of hosting a sport event on a destination brand: A test of co-branding and match-up models. Sport Management Review, 9, 49-78.

Zhang, L. \& Zhao, S. (2009). City branding and the Olympic effect: A case study of Beijing. Cities, 26, 245-254. 